\title{
Innovation activities of firms: the case of 8 cis waves in the Czech industry between 2001 and 2014
}

\author{
Marek Vokoun ${ }^{1, *}$ \\ ${ }^{1}$ Institute of Technology and Business in České Budějovice, Department of management, Okružní \\ 517/10, 37001 České Budějovice, Czech Republic
}

\begin{abstract}
Eight Czech CIS waves between 2001-2014 were analyzed. An adjusted (incomplete) CDM model was used to estimate effects of characteristics of firms (firm size, government funding, market orientation, or foreign ownership) on the innovation process (decision to innovate, R\&D intensity, sales from innovated goods). Public support had a very limited or even negative effect on innovation inputs and outputs. This analysis suggests that there is no relationship between R\&D expenditures and sales of innovated goods. The coefficients are quite similar for new-tothe-market innovators and new-to-the-enterprise innovators. The orientation of the world market is a highly important factor of new-to-themarket innovators. The ability to capture sales of innovated goods is higher for smaller firms, but only for the new-to-the-firm innovators. The analysis also showed differences between innovators in service sector and manufacturing sector. Cooperation is a positive factor of innovation intensity in the manufacturing sector; however on average, there is zero effect of cooperation in the service sector. World market orientation is a key factor of service companies.
\end{abstract}

Key words: innovation activities, firms, CDM model, Czech market, CIS

\section{Introduction}

The paper analyses innovation activities of firms on the Czech market using 8 Community Innovation Surveys (CIS), which were carried out in 2001, 2003, 2005, 2006, 2008, 2010, 2012, and 2014. The surveys on innovation activities of firms were carried out in the transition years of the Czech economy into a modern developed country. Czech economy is one of the most open economies in the world. In the selected period, firms were joining the European Union markets in 2004, had experienced economic boom in 2005-2007, and economic crisis in 2008-2012.

The objective is to analyze the long-term relationships between innovation processes and firms' characteristics. The study focuses on the repressors such as size of the firm, government funding of research and development (R\&D), and innovation input efficiency of innovation projects.

This paper explores new data from the years 2012 and 2014 and compares the manufacturing industry to the service sector. It uses two distinct definitions of innovators to

\footnotetext{
* Corresponding author: marek.vokoun@mail.vstecb.cz
} 
observe the differences between them. One is describing innovators as those who introduced an innovation new to the market and in second case innovators as those who introduced an innovation new to the firm. The method uses three stages of the innovation process suggested by innovation modeling literature. It uses the selection equation to distinguish between innovators and non-innovators and then models innovation input by R\&D expenditures and innovation output using the sales of innovated goods and services.

\section{Current literature}

Newest research focuses on the relationship between innovation and growth, and on the role of public support. Young firms are entering markets and usually try to utilize new technologies, cooperation, and in-house R\&D activities to surpass the competition. However, the relationships between innovation and growth, $R \& D$ and young firms, and efficiency of public support of R\&D are not as straightforward as one would expect.

On average, public support of R\&D didn't have a significant impact on additional private investments in Italy and a complete crowding-out effect was observed there. The positive effect was observed only in the group of smaller firms; a strong negative effect was in larger firms [1].

The European Union Framework programmes (FPs) were created to promote and support cooperative R\&D activities. The impact of FPs on firms' labour productivity is higher in comparison to randomly selected unsupported companies in the analysed years 1998-2002 [2].

There is a crowding-out effect of private $R \& D$ on innovation activities of firms, which is caused by the public support of $R \& D$ expenditures and innovation projects. The problem is that overall innovation activity is not affected by public support; supported firms only substitute their own resources by the government funding. This is the case especially for open innovation activities. Providing information resources and facilitating collaboration are examples of non-monetary public support. This non-monetary support seems to exert a stronger influence on firm's openness than monetary support which leads to a crowding out effect, i.e. does not foster open innovation in firms that are already innovative [3].

The relationship between innovation and firm growth is not straightforward. Firm growth is only explained with number of employees, capital, and sometimes with location or industry variables. It should be also analysed using specific unobservable factors related to the human and social capitals of firms. Growth of firms is observed in advanced technological environments where entrepreneurial firms are skilled at exploiting knowledge spillovers and investment is oriented at organisational flexibility [4].

Company growth is independent on R\&D intensity and R\&D investment. The Gibrat's Law (proportional rate of growth of a firm is independent on its absolute size), is rejected in their paper based on a sample of Portuguese manufacturing firms during the period from 1990 to 2001 . The causal link and dynamics are more complex and primarily focus on the investment in fixed assets, which has a positive effect on the growth of firms; for small and high-tech firms such an effect is even more noticeable [5].

Company growth depends not only on the number of employees but also on the frequency of $R \& D$ (continuous, non-periodic) and the type of innovation (process, product, organizational, and marketing innovation). Continuous product and process innovators grow in the markets, however occasional process innovators grow even more rapidly [6].

The drivers of the innovative performance of young firms in the creative sectors are based on higher R\&D intensity; greater emphasis is placed on internal R\&D activities that focus more on product innovation than on organizational or process innovations. It is also based on networking activities and more frequent use of formal or informal methods of intellectual rights protection in comparison to firms in other industries [7]. Not all young 
firms invest in R\&D in Spain between 2004 and 2010. It is because they are exporters and they have competitive goods and no need for intensive R\&D expenditures and innovation projects as non-exporters [8].

There are other factors as well. Cooperation is a factor of innovation intensity and leads to more innovation activities of firms. Cooperation strategies that incorporate knowledge intensive business service firms (outsourcing) have a considerably greater impact on introducing innovation on the market [9]. Lack of qualified human capital is a barrier for starting innovation activities and is also a serious impediment to continuous innovator firms [10]. New management techniques are most common type of innovation in service companies in Spain [11]. The results also suggest that small-sized firms are more likely to be innovators than medium and large service companies.

The entrepreneurial opportunities of innovation ideas can be measured simply by the mean expected value of a new idea and its variance that depends on the risk appetite of the economic agent and market environment. Authors developed this opportunity based framework into the knowledge spill-over theory of entrepreneurship [12]. I agree with the thesis that too strong intellectual property protection reduces intra-temporal knowledge spill-overs, innovation, and growth since all the rents are appropriated by incumbent firms and entrepreneurship and innovation activities are too uncertain.

\section{Materials and Methods}

Eight Community Innovation Survey (CIS) waves (2001, 2003, 2005, 2006, 2008, 2010, 2012 and 2014) were used for the analysis. Data from the Czech Statistical Office (CZSO) questionnaires were used and connected. They are labelled "TI" and "P5-01." There was a data loss (empty cells, zero sales, innovators with zero R\&D expenditures) but it was only for a few observations. The firm level innovation data and financial statements were not joined because CZSO no longer provides the opportunity to join data from two questionnaires. There was also a problem with discontinuity of some questions and only a few control variables were possible to create.

Table 1. Summary statistics for CIS waves in the Czech manufacturing industry.

\begin{tabular}{|c|r|r|r|r|r|}
\hline Variable & \multicolumn{1}{c|}{ Obs. } & \multicolumn{1}{c|}{ Mean } & \multicolumn{1}{c|}{ Std. Dev. } & \multicolumn{1}{c|}{ Min } & \multicolumn{1}{c|}{ Max } \\
\hline Innovator (new to the market) & 42663 & 0.16 & 0.36 & 0 & 1 \\
\hline Innovator (new to the firm) & 42663 & 0.28 & 0.45 & 0 & 1 \\
\hline Total R\&D expenditures & 42387 & 11616.37 & 146349.80 & 0 & $1.51 \mathrm{E}+07$ \\
\hline Sales form innovated goods per employee & 17996 & 2635.98 & 41875.90 & 0 & 4015001 \\
\hline Number of employees & 34913 & 259.99 & 1205.67 & 1 & 81662 \\
\hline Manufacturing & 42663 & 0.46 & 0.50 & 0 & 1 \\
\hline Services & 42663 & 0.40 & 0.49 & 0 & 1 \\
\hline Foreign ownership & 7130 & 0.40 & 0.49 & 0 & 1 \\
\hline
\end{tabular}

The data sample features $16 \%$ of innovator firms (Tab. 1), which introduced innovations new to the market. The smallest firm has one employee; there are also large firms with more 10,000 employees. As described before, the Czech manufacturing industry is characterized by the foreign presence. In the data sample, there are $40 \%$ of multinational firms.

The estimation strategy is similar to the one used [13] [14]. The first step (decision) is a Heckman procedure, which is also known as the generalized Tobit II procedure. The panel version using random effect Probit estimation is, however, used in the first equation and 
panel regression with Mill's ratio in the second equation. The second step is a fixed effects estimator of the innovation output.

Table 2. Modified CDM model.

\begin{tabular}{|c|c|}
\hline $\begin{array}{c}\text { Heckman } \\
\text { procedure }\end{array}$ & $r_{i t}^{*}\left\{\begin{array}{c}1 \text { if } r_{i t}=\left(X_{1 i t} \beta_{1}+\rho_{i}+\varepsilon_{i t_{1}}\right)>0 \\
0 \text { otherwise }\left(r_{i t} \leq 0\right)\end{array}\right.$ \\
\cline { 2 - 3 } & $k_{i t}^{*}=\ln \left(k_{i t}\right) l\left(r_{i t}>0\right)=X_{2 i t} \beta_{2}+\rho_{i}+\varepsilon_{i t_{z}}$ with $D f\left(k_{i t}\right)=(0, \infty)$ \\
\hline $\begin{array}{c}\text { Innovation } \\
\text { output }\end{array}$ & $\mathrm{t}_{\mathrm{it}}^{*}=\ln \left(t_{i t}\right) \mid\left(k_{i t}>0\right)=X_{3 i t} \beta_{3}+\rho_{i}+\alpha k_{i t}^{*}+\varepsilon_{i t_{3}}$ with $D f\left(t_{i t}\right)=(0, \infty)$ \\
\hline
\end{tabular}

$X n_{i t} \beta_{n}$ 's (with $\mathrm{n}=1,2,3$, and 4$)$ are vectors of explanatory variables and $\varepsilon_{-i}$ itn $s$ (with $\mathrm{n}=$ $1,2,3$, and 4) are random-error terms. The error terms are assumed to be independent of the exogenous variables. In the first (I.) and the second part (II.), the error term can be estimated as a system. The system of four econometric equations (Tab. 3) allows for arbitrary correlation among the four disturbances. The vector of parameters to be estimated is denoted $\beta \mathrm{n}$ (with $\mathrm{n}=1,2,3$, and 4) and the single parameters to be estimated are $\alpha$ and $\gamma$.

The first equation $\left(\mathrm{r}_{\mathrm{it}}{ }^{*}\right)$ accounts for selection into $\mathrm{R} \& \mathrm{D}$ activities. Here the interest is focused on the probability of a firm $i$ to engage in continuous R\&D in a year $t$. This is specified as a probit model, i.e. $\mathrm{P}\left(\mathrm{r}_{\mathrm{it}}{ }^{*}>0\right)=\Phi\left(\mathrm{X}_{1 \mathrm{it}} \beta_{1}\right)$, where $\mathrm{r}_{\mathrm{it}}{ }^{*}$ equals 1 if firm $\mathrm{i}$ is an innovator and reports R\&D expenditures. The second linear equation $\left(\mathrm{ki}^{*}\right)$ describes innovation input, which relates the log of internal and external R\&D expenditures (without machinery expenditures) to the number of employees in a firm $i$, conditional of being a process innovator and doing R\&D. The $\boldsymbol{\rho}_{\mathrm{i}}$ represents fixed or individual effects. In both equations, there is a number of potential determinants $\left(\mathrm{Xn}_{\mathrm{it}} \beta_{\mathrm{n}}{ }^{\mathrm{s}} \mathrm{s}\right)$ such as a firm's size, foreign ownership, being part of a group of companies, etc. The third linear equation $\left(t_{i t}{ }^{*}\right)$ models the innovation log of sales of goods and services to the number of employees. Here the aim is at the input-output elasticity $\alpha$ and other explanatory variables $\left(\mathrm{Xn}_{\mathrm{it}} \beta_{\mathrm{n}} \mathrm{s}\right)$ describing the behavior and market determinants of innovators.

\section{Results}

Eight Czech CIS waves were analyzed. The goal was to assess the differences between industries and two definitions of innovators. First six models in Table 2 and Table 3 compare new-to-the-firm and new-to-the-market innovators. The probability to innovate is positively influenced by the size of the company and being a part of a group of companies. For new-to-the-market innovators the coefficients are quite similar and slightly lower in effect. In case of employees, the coefficient size is about 0.03 lower, in case of being part of a group the coefficient is about 0.12 lower, and industry variables are also lower. Substantial differences are observable in market orientation. New-to-the-market innovators have about 0.2 higher probability to innovate in comparison to the new to the firm innovators. The probability to innovate is higher in the manufacturing industry in comparison to services and other industries such as trade. The differences between these two sectors are described in literature [15] and it is suggested to analyze these sectors separately.

New-to-the-market innovators differ in innovation intensity (R\&D expenditures per employee) when compared to new-to-the-firm innovators. Central Government support, EU funding, and cooperation positively affected the amount of $R \& D$ expenditures per employee for new-to-the-firm innovators. For new-to-the-market innovators, there is a higher R\&D intensity in the manufacturing and service industries in comparison to other 
industries. New-to-the-market multinational innovators are on average spending more per employee than domestic firms. Higher R\&D intensity is typical for smaller innovators and it is stronger for new-to-the-market innovators.

There is a negative effect of the firm's size on the new-to-the-market innovators. This effect is not present in new-to-the-firm innovators. In both cases, Framework Programmes did not contribute to higher R\&D intensity and decreased the innovation output of participated firms. Other public funding sources did not contribute to higher innovation output. The contribution is not significant because the input output elasticity ratio, i.e. the effect of R\&D expenditures on sales of innovated goods and services, was not statistically significant.

There are differences between new-to-the-market innovators in service and manufacturing sector (see Table 4 and Table 5). The probability to innovate is higher for larger companies in the manufacturing industry. The situation in the service sector is similar but the effect of firm size is lower. Significant difference is also in market orientation. World market orientation is a key factor of service companies. The probability is higher than in manufacturing industry.

The innovation intensity is highly and negatively dependent on the firm size in the service industry; the effect in manufacturing is weaker. Cooperation plays a dominant role in manufacturing and it is not statistically significant in the service sector. Public funding has an impact on R\&D intensity in the manufacturing sector. The only insignificant source was funding from the EU Framework Programmes. The funding from the central government in the service sector was the only significant source. Local government funding contributed to higher sales of innovated goods in the service sector.

\section{Conclusion}

This paper analyzed 8 CIS waves in Czech Republic in the period between 2001-2014. Adjusted (incomplete) CDM model was used to estimate variables in the panel of 24,000 observations about firms. Two definitions of innovators and two industries were selected to analyze effects of regressors (firm size, government funding, market orientation, and foreign ownership) on the innovation process (decision to innovate, R\&D intensity, sales from innovated goods).

The coefficients are quite similar and the differences between new-to-the-market innovators and new-to-the-firm innovators are not substantial. We can however observe slightly lower coefficients in new-to-the-market innovators. World markets orientation is a highly important factor of being a new-to-the-market innovator. The ability to capture sales of innovated goods is higher for smaller firms, but only for the new-to-the-firm innovators.

The first analysis showed differences between innovators in the service sector and the manufacturing sector. Cooperation is a positive factor of innovation intensity. It plays a dominant role in the manufacturing sector; however on average, there is zero effect of cooperation in service sector. World market orientation is a key factor of service companies.

This analysis explored the dataset of 8 CIS waves and suggests that the effect of R\&D expenditures on sales of innovated goods and services is not statistically significant. Public support had a very limited and even negative effect on innovation input and output as well. This analysis points to the fact that the investment in fixed assets is the most significant factor of company growth and value. 


\section{References}

1. R. Bronzini, E. Iachini, Are Incentives for R\&D Effective? Evidence from a Regression Discontinuity Approach. American Economic Journal: Economic Policy, 6, 100-134 (2014)

2. L. Aguiar, P. Gagnepain, European cooperative R\&D and firm performance: Evidence based on funding differences in key actions. International Journal of Industrial Organization, 53, 1-31 (2017)

3. M. Cano-Kollmann, R.D. Hamilton III, R. Mudambi, Public support for innovation and the openness of firms' innovation activities. Industrial and Corporate Change, 26, 421-442, (2017)

4. D. B. Audretsch, A. Coad, A. Segarra, Firm growth and innovation. Small Business Economics, 43, 743-749 (2014a)

5. B. Oliveira, A. Fortunato, Firm growth and R\&D: Evidence from the Portuguese manufacturing industry. Journal of Evolutionary Economics, 27, 613-627 (2017)

6. M. Deschryvere, R\&D, firm growth and the role of innovation persistence: an analysis of Finnish SMEs and large firms. Small Business Economics, 43, 767-785 (2014)

7. A. Protogerou, A. Kontolaimou, Y. Caloghirou, Innovation in the European creative industries: a firm-level empirical approach. Industry and Innovation, 24, 587-612 (2017)

8. D. B. Audretsch, A. Segarra, M. Teruel, Why don't all young firms invest in R\&D? Small Business Economics, 43, 751-766 (2014b)

9. D. Doloreux, R. Shearmur, Innovation Strategies: Are Knowledge-Intensive Business Services Just Another Source of Information? Industry and Innovation, 20, 719-738 (2013)

10. P. D'Este, F. Rentocchini, J. Vega-Jurado, The Role of Human Capital in Lowering the Barriers to Engaging in Innovation: Evidence from the Spanish Innovation Survey. Industry and Innovation, 21, 1-19 (2014)

11. A. Trigo, The Nature of Innovation in R\&D- and Non-R\&D-Intensive Service Firms: Evidence from Firm-Level Latent Class Analysis. Industry and Innovation, 20, 48-68 (2013)

12. Z. J. Acs, D. B. Audretsch, E. E. Lehmann, The knowledge spillover theory of entrepreneurship. Small Business Economics, 41, 757-774 (2013)

13. F. Castellacci, How does competition affect the relationship between innovation and productivity? Estimation of a CDM model for Norway (MPRA Paper 27591. B.m.: University Library of Munich, Germany) (2009)

14. B. Crepon, E. Duguet, J. Mairesse, Research, Innovation and Productivity: An Econometric Analysis at the Firm Level. Economics of Innovation and New Technology, 7, 115-158 (1998)

15. J. E. Ettlie, S. R. Rosenthal, Service versus Manufacturing Innovation, Journal of Product Innovation Management, 28, 285-299 (2011) 


\section{Appendix}

Table 3. All industries, new market innovators, Czech Republic 2001-2014.

\begin{tabular}{|c|c|c|c|}
\hline \multirow[b]{2}{*}{$\begin{array}{l}\text { All industries } \\
\text { New market innovators } \\
8 \text { CIS Waves 2001-2014 }\end{array}$} & (1) & (2) & (3) \\
\hline & $\begin{array}{l}\text { Innovator (0/1) } \\
\text { df } / \mathbf{d x}\end{array}$ & $\begin{array}{c}\text { Log of } R \& D \\
\text { expenditures per } \\
\text { employee }\end{array}$ & $\begin{array}{l}\text { Log of sales of } \\
\text { innovated goods } \\
\text { per employee }\end{array}$ \\
\hline & PROBIT RE & OLS FE & OLS FE \\
\hline \multirow[t]{2}{*}{ Log of employees } & $0.259 * * *$ & $-0.594 * * *$ & $-0.245^{*}$ \\
\hline & $(0.02)$ & $(0.20)$ & $(0.15)$ \\
\hline \multirow[t]{2}{*}{ Being part of a group } & $0.353 * * *$ & & \\
\hline & $(0.04)$ & & \\
\hline \multirow[t]{2}{*}{ Foreign company } & $-0.200 * * *$ & $0.331^{*}$ & 0.166 \\
\hline & $(0.04)$ & $(0.18)$ & $(0.17)$ \\
\hline \multirow{2}{*}{ Manufacturing } & $0.780 * * *$ & $1.321 * * *$ & 0.769 \\
\hline & $(0.06)$ & $(0.36)$ & $(1.08)$ \\
\hline \multirow[t]{2}{*}{ Services } & $0.507 * * *$ & $1.060^{* *}$ & 0.016 \\
\hline & $(0.07)$ & $(0.52)$ & $(0.88)$ \\
\hline \multirow[t]{2}{*}{ National markets } & $0.755^{* * *}$ & & \\
\hline & $(0.06)$ & & \\
\hline \multirow[t]{2}{*}{ European markets } & $0.715 * * *$ & & \\
\hline & $(0.06)$ & & \\
\hline \multirow[t]{2}{*}{ World markets } & $0.771 * * *$ & & \\
\hline & $(0.07)$ & & \\
\hline \multirow[t]{2}{*}{ Linear trend } & $0.065^{* * *}$ & 0.004 & Year dummies \\
\hline & $(0.01)$ & $(0.02)$ & \\
\hline \multirow{2}{*}{ Lack of personnel } & $0.327 * * *$ & & \\
\hline & $(0.04)$ & & \\
\hline \multirow[t]{2}{*}{ Lack of information } & $0.096^{* *}$ & & \\
\hline & $(0.04)$ & & \\
\hline \multirow[t]{2}{*}{ Prior innovation } & $-0.253 * * *$ & & \\
\hline & $(0.04)$ & & \\
\hline \multirow[t]{2}{*}{ Cooperation } & & $0.264^{* *}$ & 0.032 \\
\hline & & $(0.11)$ & $(0.09)$ \\
\hline \multirow[t]{2}{*}{ Funding - local GOV } & & 0.264 & 0.045 \\
\hline & & $(0.26)$ & $(0.22)$ \\
\hline \multirow[t]{2}{*}{ Funding - central GOV } & & $0.474 * * *$ & -0.025 \\
\hline & & $(0.11)$ & $(0.10)$ \\
\hline \multirow[t]{2}{*}{ Funding - EU } & & 0.135 & 0.203 \\
\hline & & $(0.13)$ & $(0.13)$ \\
\hline \multirow[t]{2}{*}{ Funding - UE FP } & & 0.042 & $-0.308^{*}$ \\
\hline & & $(0.15)$ & $(0.18)$ \\
\hline \multirow{2}{*}{$\begin{array}{l}\text { Log of R\&D expenditures } \\
\text { per employee }\end{array}$} & & & 0.025 \\
\hline & & & $(0.03)$ \\
\hline \multirow[t]{2}{*}{ Constant } & $-133.757 * * *$ & -2.294 & $10.258^{* * *}$ \\
\hline & $(13.05)$ & (39.27) & $(1.25)$ \\
\hline Observations & 23802 & 3378 & 3109 \\
\hline Adjusted R2 & $\mathrm{n} / \mathrm{a}$ & $4.28 \%$ & $71.26 \%$ \\
\hline
\end{tabular}

Robust Standard errors (bootstrapping) in parentheses, ${ }^{*} \mathrm{p}<0.10, * * \mathrm{p}<0.05, * * * \mathrm{p}<0.01$ 
Table 4. All industries, new to the firm innovators, Czech Republic 2001-2014.

\begin{tabular}{|c|c|c|c|}
\hline \multirow{3}{*}{$\begin{array}{c}\text { All industries } \\
\text { New firm innovators } \\
8 \text { CIS Waves 2001-2014 }\end{array}$} & (4) & (5) & (6) \\
\hline & $\begin{array}{c}\text { Innovator (0/1) } \\
\text { df } / \mathbf{d x}\end{array}$ & $\begin{array}{c}\text { Log of } R \& D \\
\text { expenditures per } \\
\text { employee }\end{array}$ & $\begin{array}{l}\text { Log of sales of } \\
\text { innovated goods } \\
\text { per employee }\end{array}$ \\
\hline & PROBIT RE & OLS FE & OLS FE \\
\hline \multirow[t]{2}{*}{ Log of employees } & $0.286^{* * *}$ & $-0.465 * * *$ & -0.258 \\
\hline & $(0.01)$ & $(0.13)$ & $(0.18)$ \\
\hline \multirow[t]{2}{*}{ Being part of a group } & $0.472 * * *$ & & \\
\hline & $(0.04)$ & & \\
\hline \multirow[t]{2}{*}{ Foreign company } & $-0.273 * * *$ & 0.202 & 0.054 \\
\hline & $(0.04)$ & $(0.14)$ & $(0.15)$ \\
\hline \multirow[t]{2}{*}{ Manufacturing } & $0.832 * * *$ & 0.299 & 0.567 \\
\hline & $(0.05)$ & $(0.39)$ & $(0.85)$ \\
\hline \multirow[t]{2}{*}{ Services } & $0.526^{* * *}$ & 0.627 & -0.134 \\
\hline & $(0.05)$ & $(0.55)$ & $(1.01)$ \\
\hline \multirow[t]{2}{*}{ National markets } & $0.472 * * *$ & & \\
\hline & $(0.04)$ & & \\
\hline \multirow[t]{2}{*}{ European markets } & $0.575 * * *$ & & \\
\hline & $(0.04)$ & & \\
\hline \multirow[t]{2}{*}{ World markets } & $0.578^{* * *}$ & & \\
\hline & $(0.05)$ & & \\
\hline \multirow[t]{2}{*}{ Linear trend } & $0.055 * * *$ & 0.003 & Year dummies \\
\hline & $(0.01)$ & $(0.01)$ & \\
\hline \multirow[t]{2}{*}{ Lack of personnel } & $0.488 * * *$ & & \\
\hline & $(0.03)$ & & \\
\hline \multirow[t]{2}{*}{ Lack of information } & $0.066^{*}$ & & \\
\hline & $(0.04)$ & & \\
\hline \multirow[t]{2}{*}{ Prior innovation } & $-0.297 * * *$ & & \\
\hline & $(0.03)$ & & \\
\hline \multirow[t]{2}{*}{ Cooperation } & & $0.264 * *$ & 0.032 \\
\hline & & $(0.11)$ & $(0.09)$ \\
\hline \multirow[t]{2}{*}{ Funding - local GOV } & & 0.221 & 0.036 \\
\hline & & $(0.17)$ & $(0.19)$ \\
\hline \multirow[t]{2}{*}{ Funding - central GOV } & & $0.443 * * *$ & -0.037 \\
\hline & & $(0.10)$ & $(0.09)$ \\
\hline \multirow[t]{2}{*}{ Funding - EU } & & $0.177 *$ & 0.133 \\
\hline & & $(0.10)$ & $(0.11)$ \\
\hline \multirow[t]{2}{*}{ Funding - UE FP } & & 0.108 & $-0.309 * * *$ \\
\hline & & $(0.10)$ & $(0.11)$ \\
\hline \multirow{2}{*}{$\begin{array}{l}\text { Log of R\&D expenditures } \\
\text { per employee }\end{array}$} & & & 0.025 \\
\hline & & & $(0.03)$ \\
\hline \multirow[t]{2}{*}{ Constant } & $-114.682 * * *$ & -0.049 & $10.422 * * *$ \\
\hline & $(11.32)$ & $(26.30)$ & $(1.34)$ \\
\hline Observations & 24289 & 5399 & 3351 \\
\hline Adjusted R2 & $\mathrm{n} / \mathrm{a}$ & $3.52 \%$ & $69.70 \%$ \\
\hline
\end{tabular}

Robust Standard errors (bootstrapping) in parentheses, ${ }^{*} \mathrm{p}<0.10, * * \mathrm{p}<0.05, * * * \mathrm{p}<0.01$ 
Table 5. Services, new to the firm innovators, Czech Republic 2001-2014.

\begin{tabular}{|c|c|c|c|}
\hline \multirow{3}{*}{$\begin{array}{c}\text { Services } \\
\text { New firm innovators } \\
8 \text { CIS Waves 2001-2014 }\end{array}$} & (7) & (8) & (9) \\
\hline & $\begin{array}{c}\text { Innovator (0/1) } \\
\text { df/dx }\end{array}$ & $\begin{array}{c}\text { Log of R\&D } \\
\text { expenditures per } \\
\text { employee }\end{array}$ & $\begin{array}{c}\text { Log of sales of } \\
\text { innovated goods } \\
\text { per employee }\end{array}$ \\
\hline & PROBIT RE & OLS FE & OLS FE \\
\hline \multirow[t]{2}{*}{ Log of employees } & $0.098 * * *$ & $-1.175^{* * *}$ & -0.854 \\
\hline & $(0.03)$ & $(0.30)$ & $(0.68)$ \\
\hline \multirow{2}{*}{ Being part of a group } & $0.564 * * *$ & & \\
\hline & $(0.07)$ & & \\
\hline \multirow[t]{2}{*}{ Foreign company } & $-0.218^{* * *}$ & 0.132 & 0.656 \\
\hline & $(0.07)$ & $(0.24)$ & $(0.46)$ \\
\hline \multirow[t]{2}{*}{ National markets } & $0.654 * * *$ & & \\
\hline & $(0.07)$ & & \\
\hline \multirow[t]{2}{*}{ European markets } & $0.461^{* * *}$ & & \\
\hline & $(0.09)$ & & \\
\hline \multirow[t]{2}{*}{ World markets } & $0.814 * * *$ & & \\
\hline & $(0.11)$ & & \\
\hline \multirow[t]{2}{*}{ Linear trend } & $0.034 * * *$ & $0.064^{* *}$ & Year dummies \\
\hline & $(0.01)$ & $(0.03)$ & \\
\hline \multirow[t]{2}{*}{ Lack of personnel } & $0.692 * * *$ & & \\
\hline & $(0.06)$ & & \\
\hline \multirow{2}{*}{ Lack of information } & -0.022 & & \\
\hline & $(0.07)$ & & \\
\hline \multirow[t]{2}{*}{ Prior innovation } & $-0.361 * * *$ & & \\
\hline & $(0.07)$ & & \\
\hline \multirow[t]{2}{*}{ Cooperation } & & 0.354 & 0.166 \\
\hline & & $(0.23)$ & $(0.29)$ \\
\hline \multirow[t]{2}{*}{ Funding - local GOV } & & -0.240 & $0.554 *$ \\
\hline & & $(0.37)$ & $(0.33)$ \\
\hline \multirow[t]{2}{*}{ Funding - central GOV } & & $0.555^{* *}$ & -0.022 \\
\hline & & $(0.25)$ & $(0.20)$ \\
\hline \multirow[t]{2}{*}{ Funding - EU } & & -0.118 & 0.137 \\
\hline & & $(0.22)$ & $(0.35)$ \\
\hline \multirow[t]{2}{*}{ Funding - UE FP } & & -0.202 & $-0.593 *$ \\
\hline & & $(0.28)$ & $(0.34)$ \\
\hline \multirow{2}{*}{$\begin{array}{l}\text { Log of R\&D expenditures } \\
\text { per employee }\end{array}$} & & & -0.068 \\
\hline & & & $(0.07)$ \\
\hline \multirow[t]{2}{*}{ Constant } & $-71.127 * * *$ & $-120.230 * *$ & $14.408^{* * *}$ \\
\hline & (24.53) & (51.06) & $(3.49)$ \\
\hline Observations & 6277 & 1156 & 675 \\
\hline Adjusted R2 & $\mathrm{n} / \mathrm{a}$ & $8.38 \%$ & $69.03 \%$ \\
\hline
\end{tabular}

Robust Standard errors (bootstrapping) in parentheses, $* \mathrm{p}<0.10, * * \mathrm{p}<0.05, * * * \mathrm{p}<0.01$ 
Table 6. Manufacturing, new to the firm innovators, Czech Republic 2001-2014.

\begin{tabular}{|c|c|c|c|}
\hline \multirow{3}{*}{$\begin{array}{c}\text { Manufacturing } \\
\text { New firm innovators } \\
8 \text { CIS Waves 2001-2014 }\end{array}$} & (10) & (11) & (12) \\
\hline & $\begin{array}{c}\text { Innovator }(0 / 1) \\
d f / d x\end{array}$ & $\begin{array}{c}\text { Log of R\&D } \\
\text { expenditures per } \\
\text { employee }\end{array}$ & $\begin{array}{l}\text { Log of sales of } \\
\text { innovated goods } \\
\text { per employee }\end{array}$ \\
\hline & PROBIT RE & OLS FE & OLS FE \\
\hline \multirow[t]{2}{*}{ Log of employees } & $0.452 * * *$ & $-0.297^{*}$ & -0.129 \\
\hline & $(0.02)$ & $(0.18)$ & $(0.15)$ \\
\hline \multirow[t]{2}{*}{ Being part of a group } & $0.365 * * *$ & & \\
\hline & $(0.05)$ & & \\
\hline \multirow[t]{2}{*}{ Foreign company } & $-0.374 * * *$ & 0.213 & -0.100 \\
\hline & $(0.05)$ & $(0.17)$ & $(0.14)$ \\
\hline \multirow[t]{2}{*}{ National markets } & $0.552 * * *$ & & \\
\hline & $(0.07)$ & & \\
\hline \multirow[t]{2}{*}{ European markets } & $0.503 * * *$ & & \\
\hline & $(0.07)$ & & \\
\hline \multirow[t]{2}{*}{ World markets } & $0.548 * * *$ & & \\
\hline & $(0.08)$ & & \\
\hline \multirow[t]{2}{*}{ Linear trend } & $0.056 * * *$ & -0.009 & Year dummies \\
\hline & $(0.01)$ & $(0.02)$ & \\
\hline \multirow[t]{2}{*}{ Lack of personnel } & $0.392 * * *$ & & \\
\hline & $(0.04)$ & & \\
\hline \multirow[t]{2}{*}{ Lack of information } & $0.106^{* *}$ & & \\
\hline & $(0.04)$ & & \\
\hline \multirow[t]{2}{*}{ Prior innovation } & $-0.241 * * *$ & & \\
\hline & $(0.04)$ & & \\
\hline \multirow[t]{2}{*}{ Cooperation } & & $0.223 * * *$ & -0.078 \\
\hline & & $(0.08)$ & $(0.09)$ \\
\hline \multirow[t]{2}{*}{ Funding - local GOV } & & $0.324 * *$ & -0.261 \\
\hline & & $(0.13)$ & $(0.17)$ \\
\hline \multirow[t]{2}{*}{ Funding - central GOV } & & $0.427 * * *$ & -0.118 \\
\hline & & $(0.10)$ & $(0.08)$ \\
\hline \multirow[t]{2}{*}{ Funding - EU } & & $0.246 * *$ & 0.168 \\
\hline & & $(0.12)$ & $(0.12)$ \\
\hline \multirow[t]{2}{*}{ Funding - UE FP } & & 0.180 & -0.169 \\
\hline & & $(0.15)$ & $(0.13)$ \\
\hline \multirow{2}{*}{$\begin{array}{l}\text { Log of R\&D expenditures } \\
\text { per employee }\end{array}$} & & & 0.039 \\
\hline & & & $(0.03)$ \\
\hline \multirow[t]{2}{*}{ Constant } & $-115.555 * * *$ & 22.705 & $10.075^{* * *}$ \\
\hline & $(13.92)$ & $(35.88)$ & $(0.82)$ \\
\hline Observations & 13294 & 3850 & 2459 \\
\hline Adjusted R2 & $\mathrm{n} / \mathrm{a}$ & $3.31 \%$ & $73.12 \%$ \\
\hline
\end{tabular}

Robust Standard errors (bootstrapping) in parentheses, $* \mathrm{p}<0.10, * * \mathrm{p}<0.05, * * * \mathrm{p}<0.01$ 